\title{
Puerto Rico
}

National Cancer Institute

\section{Source}

National Cancer Institute. Puerto Rico. NCI Thesaurus. Code C17043.

An island between the Caribbean Sea and the North Atlantic Ocean, east of the Dominican Republic and west of the British Virg in Islands. 